\title{
Historical Vignette: Cerebral Cortical Stimulation and Surgery for Epilepsy
}

\author{
F. Maroun, W. Fitzgerald, T. Rasmussen, J.C. Jacob, M. Sadler and G. Murray
}

\begin{abstract}
In 1909, in an isolated community hospital, on the northern tip of the Province of Newfoundland and Labrador, Canada, Dr. John Mason Little, Jr. performed electrical stimulation of the cerebral cortex, prior to cortical excision, as treatment of recurrent cerebral seizures in three patients. Extracts from Dr. Little's written records of the clinical features, the neurosurgical procedures and cerebral cortical stimulation are summarised. A brief review of the contemporaneous history of neurosurgical procedures for epilepsy provides a prospective of Dr. Little's remarkable surgical virtuosity.
\end{abstract}

RÉSUMÉ: Vignette historique: stimulation cérébrale corticale et chirurgie dans l'épilepsie. En 1909, dans un hôpital communautaire isolé sur la pointe nordique de la province de Terre-neuve et du Labrador, Canada, le Docteur John Mason Little effectue la stimulation électrique du cortex cérébral chez trois malades souffrant de crises épileptiques à répétition. Des extraits des dossiers écrits par le Dr. Little sur les manifestations cliniques, les opérations neurochirurgicales et la stimulation corticale cérébrale sont résumés. Une brève revue de l'histoire comtemporaire des opérations neurochirurgicales pour épilepsie fournit une prospective sur la virtuosité chirurgicale remarquable du Docteur Little.

Can. J. Neurol. Sci. 1996; 23: 303-307

Dr. Wilfred Grenfell initially came to the Labrador coast, as physician and missionary to the British fishing fleet, in 1892 . He returned the following year and began the first hospital in the community of Battle Harbour on the Labrador coast. Hospitals subsequently sprang up in Indian Harbour and in St. Anthony (Figures 1 and 2). He travelled widely, soliciting support for his work; and eventually broke with the Royal National Mission to Deep Sea Fishermen and formed what became the International Grenfell Association; which, until recently, administered health care in Labrador and northern Newfoundland (Canada).

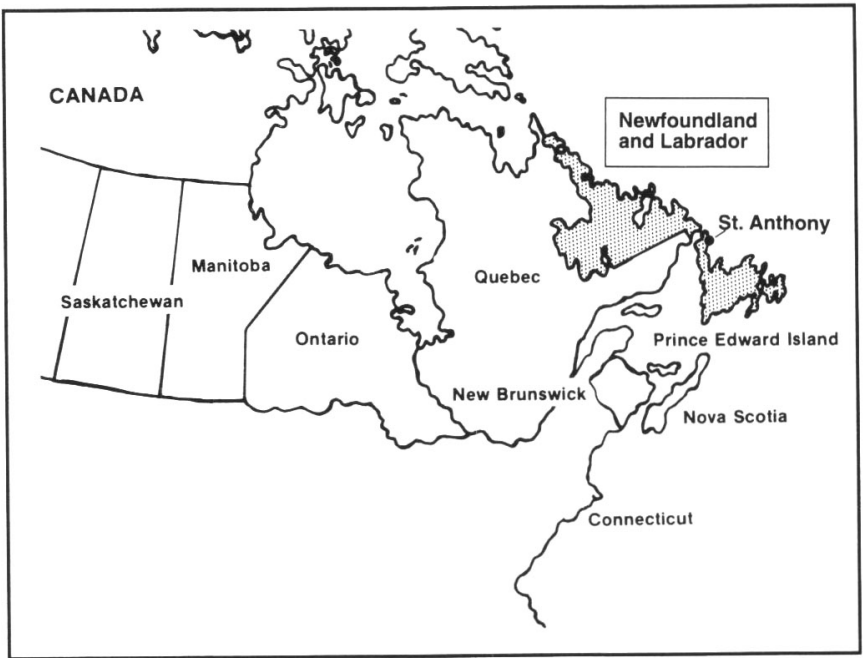

Figure I: Geographical location of St. Anthony in the province of Newfoundland and Labrador, Canada.
John Mason Little (Figure 3) was born into a wealthy Bostonian family in 1875. He graduated in 1901 from Harvard Medical School. After a year in Vienna, he spent 5 years at the Massachussets General Hospital as a surgical resident under Dr. Samuel Mixter, where he became his assistant and protégé. In the summer of 1907, he came to the Labrador coast, working out of St. Anthony, and continued his medical work till 1915.

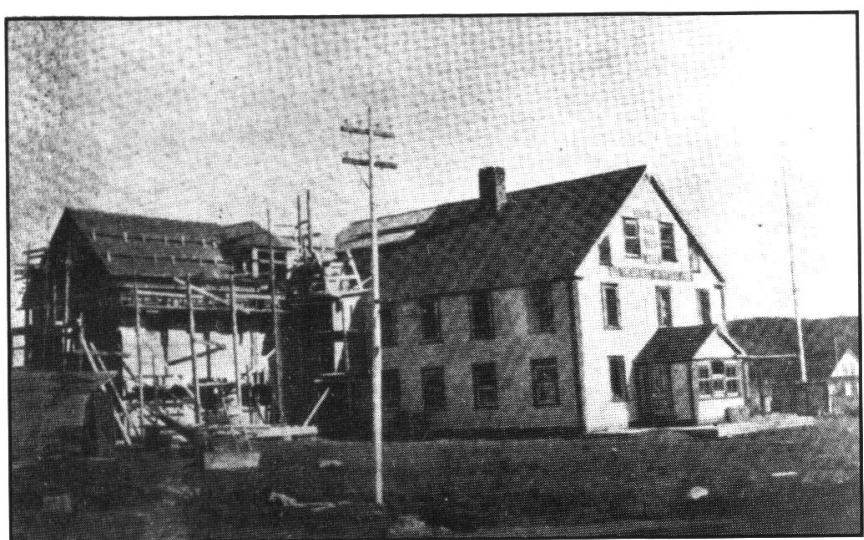

Figure 2: St. Anthony Hospital 1909, where brain surgery and electrical stimulation were carried out by Dr. Little.

From Memorial University of Newfoundland, St. John's, (F.M., J.C.J., G.M.), and Curtis Memorial Hospital, St. Anthony, (W.F.) Newfoundland; Montreal Neurological Inscitute, Montreal, (T.R.); Dalhousic University, Halifax, Nova Scotia, (G.M.). RECEIVED FEBRUARY 27, 1996. ACCEPTED IN FNAL FORM APRIL 18, 1996.

Reprint requests to: Dr. F.B. Maroun, Discipline of Surgery, Faculty of Medicine. Memorial University of Newfoundland, Healıh Sciences Centre. St. John's, Newfoundland, Canada A1B 3 V6 


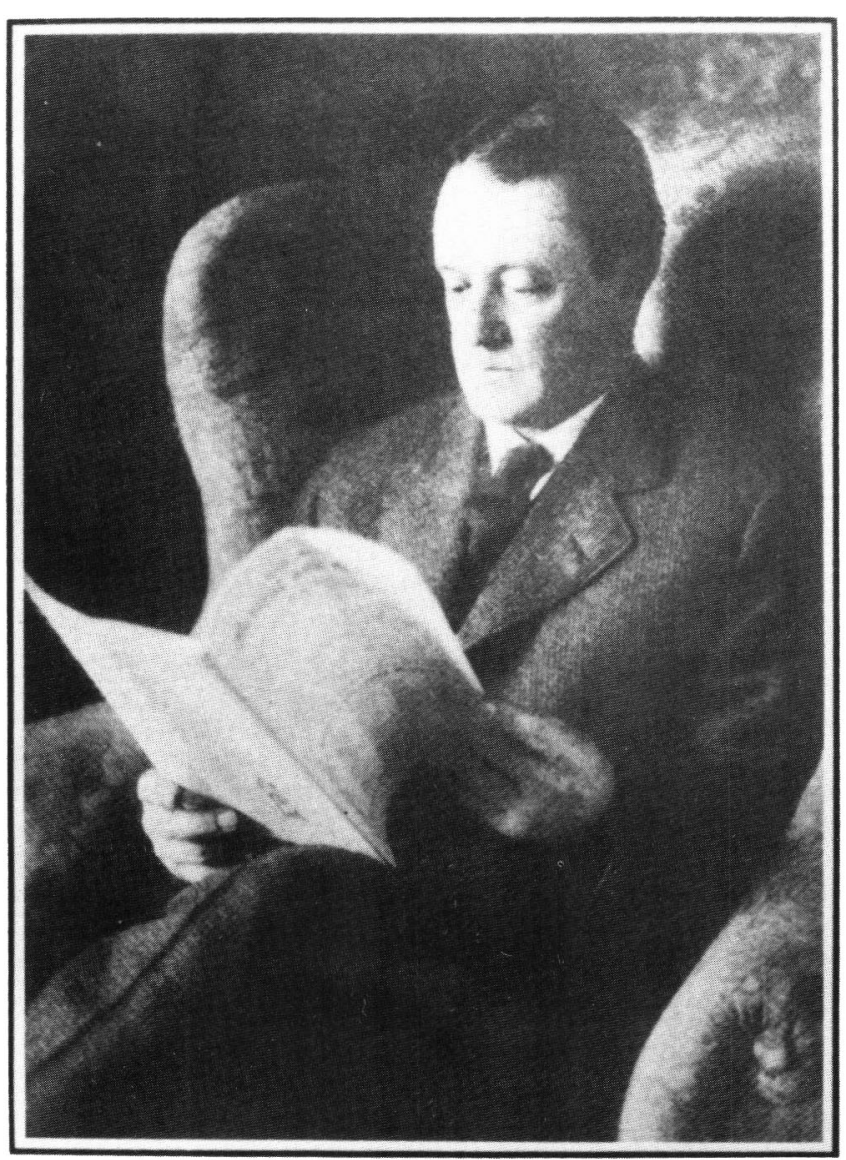

Figure 3: John Mason Little (1875-1926)

He spent a five month sabbatical as a clinical observer at the Mayo Clinic in 1910.

Dr. Little became the surgeon in St. Anthony. His surgical abilities are summarised by Grenfell:" "Exceeding skill and great experience as an operating surgeon". His enthusiasm to recruit American practitioners to St. Anthony prompted him to write two articles in the Journal of the American Medical Association. He stated "One is dependent entirely on oneself up here and that is a stimulus which should be invaluable and which, I think, is too often absent in the work at our large centres". Dr. Little also conducted scientific research, studying the effect of diet and hygiene in beriberi. He contributed to the public health policies for the Northern region of Newfoundland and Labrador. Ronald Rompkey ${ }^{2}$ in his biography of Grenfell of Labrador describes Dr. Little as "an outdoorsman, singer and bon viveur". On his return to Boston, Dr. Little continued professional activities in clinical surgery and medical administration. He was a surgeon in the Outpatient Department at the Massachussets General Hospital for 10 years. He held the post of instructor in surgical technique at the Harvard Medical School and was the chief surgeon of the Boston and Albany Railroad. He continued to serve the Grenfell Mission as a Director and President of the New England Grenfell Association. His death, at $51 \mathrm{y}$, was attributed to a "tumour near the heart", and as instructed in his will, his ashes were returned to St. Anthony.

\section{Case Reports}

\section{Patient 1: F age 17 y (1909) \\ History} time".

At age $7 \mathrm{y}$. hit on top of forehead by a rock "but didn't mind it at the

One year later "had her first attack of unconsciousness lasting one hour. No trouble in her hand".

"After this about every month on an average, she would have an attack. Never felt bad after attacks, but her right arm would feel tired. Her people never noticed any contractions in it during attacks however".

"About 3 years ago the attacks began to come more often, 2-3 times a week and her right hand was affected in them, was drawn up and stiff. Always with first part of attack she would feel a little aching queer feeling in the fore and middle finger of right hand".

"Attacks became oftener and oftener, every 3-4 days". Attack witnessed during examination. "I had just been talking to her. She was sitting up in bed leaning against pillows after tea. Suddenly her fingers of right hand twitched and her head fell back on the pillow, the eyes open and vacant looking. Her hand and arm became rigid, then her leg on same side. All the muscles were affected, the arm bent up and flexors being the stronger, the legs extended. I took her left hand and asked her to squeeze my hand if she understood. She did so..."

\section{Operation (April 12th, 1909) Chloroform (Figure 4)}

"Morphine Gr. 1/4 was given subcu. 15 minutes before being brought to the operating room. The important landmarks were marked with the point of the knife and after thorough scrubbing, etc., a trap door flap with its base $31 / 2$ inches long, was cut down to the bone and hemorrhage quickly controlled with snaps. The flap was designed to uncover the motor area at its centre or arm area. The periosteum was quickly separated a short distance back from incision and with Doyen's drill a hole was made through the skull. It was planned to turn back a bone flap but the skull was pathologically thick and very hard and the plan was abandoned. With Devigis Bone Cutter the opening was enlarged, the dura was very adherent and had to be carefully separated away from the skull. This was done and with Rongeur Forceps the opening was made large. There was bulging of the dura and no visible pulsation. Evident pressure. The hole was made 2 $1 / 2$ inches $X 11 / 2$ inches uncovering from $3 / 4$ inches from the parietal suture downwards, and its long diameter being fore and aft. The dura was opened by an incision and the brain beneath looked very "wet" and oedematous. Stimulation of the cortex was then attempted with an electrode (as per diagram) and a magneto of certified 90 volt power (Figure 5). No response was elicited. The patient was very lightly chloroformed, none at all having been given or was given after the bone was removed. The electrode was tried dry and wet. The attempt was abandoned. The brain was explored with the finger in all directions but nothing felt. Over what I conceived to be the centre of the arm motor area, (Rolandic Fissure having been identified) I thought the brain tissue looked a little discolored. I opened the pia here, and incising the cortex examined it and also with the tip of the finger but nothing could be found. The brain substance bulged a little through this opening and I scraped a little of it away. I then cut the dura away to within $1 / 4$ inch of the bone edge. Tied a couple of bleeding points in the brain substance with 00 plain catgut. The pulsation of the brain had by this time returned and the brain was bulging to a level with the outer table. The skin flap was replaced and carefully sutured with interrupted S.W.G. (Silk Worm Gut).

Trephining. Decompression, attempted electrical localization of motor area in cortex. Exploration of brain.

\section{Follow-up}

No neurological deficit - free of seizures for 2 years. Seizures recurred after but less frequent than pre-op. Died at age 40 y from unrelated illness.

\section{Patient 2: F 10Y}

At 2 years of age patient had a sudden fever, on which on day 2 patient was paralysed on left side. During recovery there was a twitching thru the affected areas. Complete recovery in a month". "Onset of present illness 15 months ago, with a twitching in the left hand, occurring at intervals of 7-8 days and not attended by unconsciousness". Major seizures occurred shortly after. "A typical fit, according to the parents, begins with a twitching in the left hand. This gives the patient at least one minute's warning..." "From hand the twitching spreads up the left arm, thence it spreads to left leg and left side of face for 5 minutes. She is able to talk during early stage of fit". 


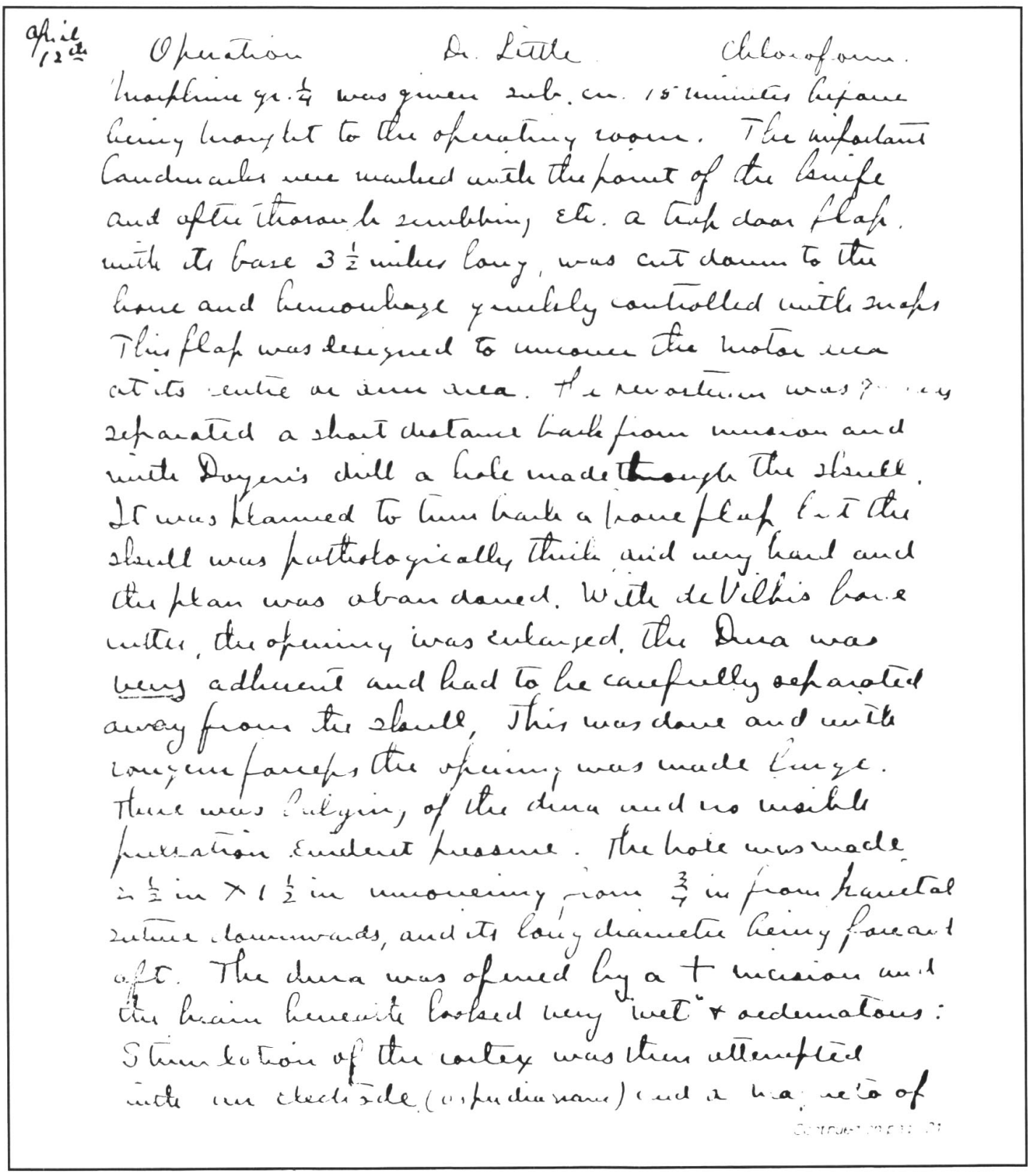

Figure 4. Hand-written operative notes by Dr: Mason Little, Jr.

Operation 1. Feb. 21, 1910

"Head shaved. No scars of any kind on scalp. Measurements made and fissures marked with knife".

Shock due to blood loss from opening after removal of bone. Bleeding from sinus treated with "coffee shock enema and an intravenous infusion of a pint of salt solution with adrenalin $1 / 1000$ ". Operation abandoned.

Operation 2. Feb. 24, 1910

Re-opening: "Dura was examined but nothing pathological was found. The dura was then opened by a crucial incision, its centre being as near as possible over the supposed arm area as calculated by measurements.

"Faradic Current to This Area Produced Movements in Left Hand and Rolandic Fissure was Identified."

"Directly in front of the arm area was a whitish scar-like looking lesion apparently involving the pia and cortex and extending across the sulci. This was irregularly shaped of about the size of $1 / 2$ a postage stamp. The arm and leg areas were mapped out by means of faradisation and were very easily defined". "The lesion suggested healed tuberculosis and no response was noted to stimulation over the lesion". No removal was carried out. "Decompression - exploration of brain - localisation of centres by means of electricity". No P.O. complications.

Follow-up (by letter)

"Child improved. Does not have fits too often. Generally goes over a month without having one. Nothing mentioned as to the nature or severity of the fits".

Patient 3: M. 20 Y 1911

History

"Father died of "sore leg". One brother died of consumption. Always well until present trouble began. Four years began to have fits. Usually had 2 or 3 fits one day at intervals of a month or two". Free of seizure for one year then recurrence. One attack per week. "Convulsions begins without an aura and the unconsciousness lasts from one to two hours. They are followed by severe headaches. Patient is told that he foams at the mouth". "Was left under observation for 3 weeks and watched in a good many fits. No aura could be made out or any localising symptoms. The head was generally turned to the left and the spasms were perhaps more severe on that side". 




Figure 5: Electrode used by Dr. Little - own drawing and handwriting "I think the current was too small but we had no better at our command. Though certified at 90 volts, we had no method of knowing that this was correct. It would not cause contraction of the thenar muscle".

\section{Operation Sept. 30, 1911}

"In right temporal area skin scar $1 / 2$ inch long". Subtemporal decompression was carried out - no complications. "Stitches removed on the 8th day". No stimulation.

Follow-up (by letter)

"Still subject to fits as often as before the operation. Under treatment with local doctor".

\section{Discussion}

The excitability of the cerebral cortex was first confirmed in 1870 by Fritsch, Hitzig ${ }^{5}$ and later confirmed by Ferrier. ${ }^{6}$ Fritsch \& Hitzig using galvanic current on the anterior lobes of animals observed contralateral movement. If the current was feeble the contractions were limited to groups of muscles and if strong, global movement of limb was noted. Ferrier concluded that all parts of the brain in front of the Sylvian fissure produced motor action, and behind sensory response. Dufuy and Carville ${ }^{7}$ suggested that Ferrier's observations, since the results obtained by Faradisation resulted in violent epileptiform movements, were probably due to spread of the current to the "central ganglia".

In 1874 , Bartholow 4 presented his results of cortical stimulation in 6 patients; he concluded with this sentence: "It has seemed to me most desirable to present the facts as I observed them, without comments". Bartholow used galvanic current from a siemens and Halske cup battery. He also used Faradic current from galvano - Faradic company's double cell battery with insulated needle electrodes. Localisation of the motor area was studied by a method of unipolar faradisation by Sherrington and Gunbaium on the anthropoid brain and later confirmed in
Table: Historical Summary of Epileptic Surgery.

\begin{tabular}{|c|c|c|}
\hline Author & Year of Report & Clinical Summary \\
\hline Astley Cooper & $1758-1841$ & $\begin{array}{l}1 \text { patient with post head } \\
\text { injury epileptic fits }\end{array}$ \\
\hline W.C. Wells & 1812 & $\begin{array}{l}\text { Epilepsy post R parietal } \\
\text { depressed skull fracture. } \\
\text { Removal of bone spicule }\end{array}$ \\
\hline Benjamin Dudley & 1828 & $\begin{array}{l}5 \text { cases of post traumatic } \\
\text { epilepsy }\end{array}$ \\
\hline Bavon Larrey & 1829 & $\begin{array}{l}\text { Focal epilepsy complicating } \\
\text { cavies of the skull; attacks } \\
\text { could be precipitated by } \\
\text { digital pressure (on scalp) }\end{array}$ \\
\hline Heyman & 1831 & $\begin{array}{l}1 \text { patient focal epilepsy due } \\
\text { to abscess }\end{array}$ \\
\hline Billings & 1861 & $\begin{array}{l}2 \text { patients focal epilepsy; } \\
\text { fatal outcome }\end{array}$ \\
\hline Samuel Gross & 1872 & $\begin{array}{l}4 \text { patients operated for focal } \\
\text { epilepsy; } 3 \text { deaths }\end{array}$ \\
\hline Horsley & 1886 & $\begin{array}{l}\text { Post trauma focal epilepsy - } \\
\text { I patient }\end{array}$ \\
\hline Keen & 1888 & 3 cases of excision of scar \\
\hline Ernest von Bergmann & 1889 & \\
\hline Krause & 1910 & $\begin{array}{l}\text { Follow-up results on } 29 \\
\text { patients operated for focal } \\
\text { epilepsy }\end{array}$ \\
\hline Earl & 1919 & \\
\hline
\end{tabular}


man by Krause and Frazier. Prior to his classic paper in 1908 on stimulation of the post central gyrus in 2 patients, Cushing ${ }^{3}$ using weak faradic current and platinum wires stimulated the cortex of more than fifty anaesthetised patients.

In 1928, Penfield ${ }^{1}$ initially used galvanic current for motor and sensory responses and faradic current to reproduce the patient's aura. In 1939, the thyratron stimulator was used. It produced a faradic current with wave frequency of 55-65 per second and intensity which was calibrated in arbitrary units. In 1945 the Rahn stimulator provided a toothed wave form with variable control of both frequency and voltage of the stimulating pulses. In 1951 the square wave stimulator was introduced, giving an independent control of pulse duration, frequency and voltage of the stimulating current: $2-4$ second trains of 2-5 milliseconds square wave pulse at a frequency of 60 pulses per second and intensity of $1-5$ volts.

The above data briefly reviewed indicated that the 3 cases of brain stimulation by Dr. Mason Little are the first on record in Canada. (In 1909 Newfoundland and Labrador was a Colony).

In his review of the history of neurosurgical intervention in the management of focal epilepsy, Penfield ${ }^{8}$ cited several reports (see Table).

Dr. Little's neurosurgical procedures, in 1909 and 1910, when viewed in this historical perspective are a remarkable testimony to his surgical innovation and skills. In particular, considering that the contemporaneous neurological procedures (referred to by Penfield) were performed at major medical centres, Dr. Little's courage in such formidable neurosurgical procedures, in the setting of a remote community hospital, is awe inspiring.

\section{REFERENCES}

1. Rasmussen T. Cortical Resection for Epilepsy: Then and Now. Churchill Livingston, Edinburgh: 183-206.

2. Rompkey R. Grenfell of Labrador: A Biography. University of Toronto Press 1991.

3. Cushing $\mathrm{H}$. A note upon the faradic stimulation of the post central gyrus in conscious patients. Brain 1909: 32; 44-53.

4. Bartholow R. Experimental investigations into the functions of the human brain. Am Med Sci 1874: 134; 305-313.

5. Fritsch $T$ and Hitzig E. (cited by Bartholow R, Archiv J Anat Physiol U Wiesenschaftliche Medecine, 3, 1870.

6. Ferrier D. (cited by Bartholow R) West Riding Lunatic Asylum Reports, Vol 3.

7. Dupuy E, Carville M, Ferrier D, Nitzi E, Fritsch T. (cited by Bartholow R, Gazette Medicale de Paris, Nos 2, 3 and 4, 1874).

8. Penfield $W$ and Jasper H. Epilepsy and the Functional Anatomy of the Human Brian. Little Brown \& Co., Boston 1954, Ch. 18: 740-745. 